INTERNATIONAL JOURNAL OF MULTidisciplinARY RESEARCH AND ANALYSis

ISSN(print): 2643-9840, ISSN(online): 2643-9875

Volume 05 Issue 01 January 2022

DOI: 10.47191/ijmra/v5-i1-14, Impact Factor: 6.072

Page No.- 95-106

\title{
The Importance of Employee Competence and Technology in Mining Increases The Performance of Village-Owned Enterprises (Bum Desa)
}

\author{
Putu Somiartha ${ }^{1}$, Ni Nyoman Yuliarmi ${ }^{2}$ \\ 1,2 Faculty of Economics and Business, Udayana University, Bali - Indonesia
}

\begin{abstract}
The presence of Law No. 6 of 2014 on Villages provides a legitimate umbrella for the establishment of BUM Desa as a village financial manager that oversees the potential of villages to work on government assistance to residents together. The development of BUM Desa, to encourage the social welfare of the community through established business units, has not been in line with expectations. Permendesa Number 4 of 2015 on the establishment, management, and dissolution of village-owned enterprises is a guideline for regions and villages in the formation and management of BUM Desa. The existence of laws and regulations is not enough for every village to establish BUMDesa. There are hundreds or even thousands of villages that even to this day have not established BUM Desa. The cause of the condition that occurs is due to the obstacles that occur in the village. It is necessary to know the obstacles experienced by most villages in Bum Desa so that they cannot run according to the goals or expectations expected by the government.

Addressing the problems that occur above the importance of the government's role to regulate strategies in improving the performance of existing village BUM Desa In terms of the performance of BUM Desa which has been there lately, has actually experienced a fairly good improvement. However, in order to improve the performance of BUM Desa there are things that need to be considered, namely employee competence. Facing the era of globalization, competition between companies will be higher, and one of the keys to success in winning the competition is the need for quality human resources. For that reason, BUM Desa is expected to be more selective in choosing employees or SDM who have competencies that refer to good performance. The second factor that has an important effect on the performance and welfare of BUM Desa employees is information and communication technology. The technology in the existing village of BUM Desa can be said to be inadequate. Technology is a driving factor of the production function. It can be said so because if modern technology is used, the resulting production will be more efficient and with a relatively shorter time frame.

The research method used is literature review. The results obtained in improving the performance of BUM Desa competency factor plays an important role in improving the performance of BUM Desa. In the management of BUM Desa to be better, employees must have knowledge, job skills, high responsibility for a job, and good motivation. If this can be applied, it is believed that the existing village bum can develop well as well.

Faktro technology has a very important role in the performance of organizations, especially BUM Desa. Without technology in the BUM Desa organization, all organizational activities in the form of information, marketing, and planning will be slow, which has an impact on the performance of BUM Desa. The maximum utilization of technology makes it easier for BUM Desa managers to work well in promoting a product, finding information, and accessing the development of BUM Desa.
\end{abstract}

KEYWORDS: Competence, Technology, and Performance of BUM Desa

\section{INTRODUCTION}

INDONESIA'S DEVELOPMENT MUST START FROM THE PERIPHERY AND STRENGTHEN RURAL AREAS THROUGH THE FRAMEWORK OF THE UNITARY STATE, WHICH IS PART OF THE NINE PLANS OF THE PRESIDENT Of THE REPUbliC Of INDONESIA WITH THE CONCEPT OF NAWACITA. NAWACITA IS A "GREAT VALUE CONCEPT," REFERRING TO THE THREE MAIN PROBLEMS FACING THE STATE IN THE STRUGGLE TO ACHIEVE NATIONAL GOALS, INCLUDING (A) DECLINING STATE AUTHORITY, (B) WEAKENING THE NATIONAL ECONOMY, AND (C) THE EMERGENCE OF PERSONALITY CRISES AND INTOLERANCE IN INDONESIA. THIS IS AN IMPORTANT TYPE OF DEVELOPMENT POLICY IN WHICH ESTABLISHING DEVELOPMENT IN THE MOST MARGINALIZED AREAS, SUCH AS VILLAGES, BECOMES A SIGNIFICANT MILESTONE TOWARD BEING ABLE TO COMPETE GLOBALLy (ABDUL MAULANA, 2016). 


\section{The Importance of Employee Competence and Technology in Mining Increases The Performance of Village-Owned Enterprises (Bum Desa)}

As part of the district, the village has retained its original autonomy. This autonomy gives the village the authority to organize and take care of its own interests by utilizing its potential. The autonomy of the village that exists as part of regional autonomy, which is contained in Law No. 32 of 2004 on Local Government, Article 1 Paragraph (5), reads: "Regional autonomy is the right, authority, and obligation of autonomous regions to regulate and take care of their own government affairs and the interests of local communities in accordance with the laws and regulations." Widjaja (2014), stated that the things to be achieved in the affairs of the region include: developing various fields in each region, improving services to the community that need to be improved, growing and increasing regional independence and competitiveness in the process of growth. The village government, in its existence to exercise autonomy, must involve the participation of the community to participate in government and development activities. This is because the village government is closest and directly deals with the community. Each village is authorized and responsible for regulating and managing the affairs of the village government for the economic survival of the village and the welfare of its people.

Adisasmita (2013) stated that rural economic institutions remain an important part, as well as being a weak point in realizing the economic independence of the village. This must be seen by observing the existence of cooperatives, especially the Koperasi unit Desa (KUD) which has been around a long time and is dynamic with its ups and downs, but its achievements are generally still few. Therefore, regular efforts are still expected to support planned village companies to be able to deal with the limitations of key financial assets in the village, as well as encourage organizations to increase strength, perhaps even financial seriousness.

To improve the welfare of the village, the village can establish a business entity commonly called the "Village Owned Business Entity" (BUM Desa). The existence of Law No. 6 of 2014 on Villages provides a legal umbrella for the establishment of BUM Desa as a village economic actor who manages the potential of each village collectively aimed at improving the welfare of villagers. BUM Desa Institution is an economic institution that aims to improve the welfare of village communities and the village economy. This means that BUM Desa as one of the mainstays of village development, is relied upon to make the village independent and useful in taking care of its own household so that the village does not only rely on the village spending budget (funds) that have been given by the central government.

The establishment of BUM Desa capital is mainly sourced using village funds derived from the central governments giving to the village. With capital assistance from the central government, BUM Desa can explore and develop the potential that exists in the village for the welfare of the community. BUM Desa as a people's economic institution, as a commercial institution, the first thing that needs to be done is to meet the needs (productive and consumptive) of the community by conducting distribution services for the provision of goods and services such as procurement of community needs that are not burdensome (such as cheaper prices and easy to get) and profitable.

Bum Desa is right and great. The managers are a structure to understand the economy of the majority of the country in power. The realization of BUM Desa as a financial foundation for the village network affects the turnaround of public finances. Finally, the sovereign State of Indonesia is ready monetarily to face the difficulties of globalization on the scale of local and world finance.

The development of BUM Desa in Indonesia has been good. From the data obtained, the number of BUM Desa continues to increase, from 1,022 units in 2014 to 50,199 units in 2019. This is because of the huge enthusiasm shown by the village government and its community to establish BUM Desa for the purpose of changing the wheels of the village economy in every province. However, through business units built by the development of BUM Desa in an effort to encourage the socio-economic welfare of the community, it has not been in line with expectations. Referring to Permendesa Number 4 of 2015 on establishment, management, and dissolution of village-owned enterprises, these become guidelines for regions and villages in the formation and management of BUM Desa. The reality is that what happened there is still many villages and even to this day has not established BUM Desa (https://www.jurnalbengkulu.com). This condition occurs for no other reason than the obstacles that occur in the village and the obstacles experienced by most BUM Desa, so it does not run according to the goals or expectations expected by the government.

Some forms of problems that really need to be considered, such as the problem of limited human resources and lack of creativity in managing BUM Desa, lack of supporting facilities such as poor technology, inadequate facilities and infrastructure, no common understanding of BUM Desa, not yet conducive business climate, information and market access are still limited, low performance (low technology), and the low soul and entrepreneurial spirit of employees that impact the performance of BUM Desa itself. 


\section{The Importance of Employee Competence and Technology in Mining Increases The Performance of Village-Owned Enterprises (Bum Desa)}

Addressing the problems that occur above the importance of the government's role to regulate strategies in improving the performance of BUM Desa. Performance factors are very important in increasing business income, which will later be for the welfare of employees or managers of BUM Desa. According to research conducted by (Alfirdausi \& Riyanto, 2020), the benefits of the existence of BUM Desa to the community are the many programs offered by the village to the community, reducing unemployment, and providing assistance to people who want to start an enterprise. In the formulation of a strategic planning organization, it contains a list of what to achieve. In general, performance is the sum of an institution's or organization's accomplishments over a given time period (Kurniawan, 201). The form of BUM Desa performance that can be described as, for example, in terms of service aspects, can serve the community well, in terms of accountability, can accommodate various government programs, and judging from the aspect of improving living standards, can have additional income from BUM Desa.

Looking at the performance of BUM Desa in recent years, it has actually experienced an increase as the results of research conducted by Suriadi \& Thamrin (2019) showed that BUM desa and Sei Rampah institutions developed well over the last 2 years since 2017. This happens because BUM Desa and Sei Rampah, together with management, continue to reform in all aspects of BUM Desa relationship in order to do development in terms of local resources, namely by utilizing village communities who are members of BUM Desa to be involved in the development of BUM Desa in the future. With various other institutions, the existence of BUM Desa increasingly exists in the running of its business wheels. Other research conducted by Soejono (2021) shows that financial performance analysis, and Force Field Analysis (FFA). Financial results fall into the category quite well, as revenue rates, net income, ROI, ROE, and NPM fluctuate. Customer perspective is in the good category because customers are satisfied with BUM Desa service, but employee productivity is in the category of quite good, because employee performance is volatile. The supporting factor of BUM Desa consists of various business units such as commercial units, savings and loan units, service units, livestock business units, and tourism units. Conversely, the inhibiting factor of BUM Desa is the establishment of standard operating procedures (SOP) in each business unit. The conclusion of the study shows that the overall performance of BUM Desa is quite good.

In order to improve the performance of BUM Desa in every village, there are several things that need to be considered, namely the competence of employees. Facing the era of globalization, competition between companies will be higher, and one of the keys to success in winning the competition is the need for quality human resources (HR), and human resources that have competencies that refer to good performance. For this reason, the company is required to be more selective in choosing the human resources that will be employed. Competence is defined as a skill and behavior used to improve performance, circumstances, or quality that is adequate or highly qualified and has the ability to demonstrate a specific role of technology (Sedarmayanti, 2017). This is supported by several studies conducted by Soetrisno \& Gilang (2018); Dwiyanti, Heryanda, and Susila (2020) and Luciana (2014) whose results from these three studies are the same, equally stating that competence has a positive influence on performance.

His problem of employee competence is still the main problem faced in every BUM Desa. The level of education of BUM Desa managers, who mostly have high school education levels, and the knowledge of managing BUM Desa are still very limited, which will affect the good or bad performance of the existing BUM Desa

Regardless of the level of education, the issue of the existence of BUM Desa actually does not have the option to attract a younger age as administrators. You could say there are still many BUM Desa in Indonesia that are less desirable for most young people to work to build BUM Desa in the village. Many village governments prefer not to use the millennial government to foster BUM Desa. One of the obstacles is that it is still difficult to convince the younger generation that BUM Desa can guarantee government assistance for its activists. Bum Desa is a hope that they can use for social and monetary assistance from the village's local government. The lack of involvement of millennials makes BUM Desa actually faced with business reasons that are made up or run with customary models because they are controlled by a more established age. Perhaps, a younger age and an older age should be synchronized with each other to realize an independent village through BUM Desa.

The role of the government is needed in overcoming this problem by providing training on BUM Desa so as to provide stimulation for managers or employees to be more detailed in the field of BUM Desa. If the competence of employees or managers increases, it will affect the performance of BUM Desa and the welfare of employees who will improve. The second factor that affects the performance and welfare of BUM Desa employees is information and communication technology. The technology in the existing BUM Desa can be said to be inadequate. Adequate information and communication technology (ICT) is needed to assist in the management of BUM Desa. Technology is a driving factor of the production function. It can be said so because if a technology is used properly, then the resulting production will be more efficient and with a relatively shorter time 


\section{The Importance of Employee Competence and Technology in Mining Increases The Performance of Village-Owned Enterprises (Bum Desa)}

frame. Technology problems in BUM Desa are influenced by many factors, including the ability of human resources to develop technology, and the continued lack of technology procurement due to the availability of capital that is still lacking. Technology is a tool used to accelerate the production process in a business. The existence of these tools, makes it very easy for workers to produce goods and will improve the performance of the workers, which will ultimately affect income levels. As research conducted by Maskarto Lucky Nara Rosmadi (2021) and states, small and medium-sized businesses have mostly involved technology in managing their businesses, especially in marketing existing products.

The use of social media is very supportive in product marketing at this time because it can streamline the work of the workforce, which can improve performance and income earned. As seen from the results of existing research, adequate technology is needed at bum desa institution to always experience new changes. In accordance with the opinion of Suparmoko and Irawan (2010) and Sudibia (2020), technology is a change in the function of production that appears in existing production techniques. Therefore, technical changes are always attempted so that there are changes and maximum use is produced in order to produce maximum performance so that it is in accordance with the income and welfare of the community.

The development of information technology today has created a competitive advantage for the business world. Within a few decades, there are four types of technologies whose development is relatively prominent, including information technology, manufacturing technology, transportation technology, and communication technology. Of the four types of technology that are growing rapidly, information technology is the most dominant in impacting the business environment.

The role of information technology as a tool in business decision making at various functions and managerial levels has become very important for business managers, especially in improving the financial performance of a company. One of the controversial issues in the field of economics of information technology is whether information technology contributes to creating added value for companies. Within its limits, it is stated that information technology has turned into a "key must" or simple device, and not a spring that has the upper hand.

Enormous work is displayed in data frameworks near association home administration to gain survival and productivity, as well as the achievement of hierarchical methodologies Kenneth C Laudon and Jane P Laudon (2004). Meanwhile, in a period of data globalization, information technology users can make their hands over associations (A.O'Brien, 2008), including supporting authoritative tasks, delivering to internal and external meetings, examining competitor exercises, and setting the pace of administrative choices that empower foundations to improve and adapt quickly to climate change. Advances in information technology must be coupled with the association's desire to proactively skip all improvements and seek to open new business doors.

Information technology investment decisions are generally taken with short-term considerations (Tallon and Pinsonneault, 2011). Information technology is also capable of creating and improving organizational performance in the medium and long term (Hazzan et al., 2009). Some research trends find that some organizations invest in strategic applications that are directly related to consumers (Tallon and Pinsonneault, 2011). The implementation of digitalization in BUM Desa has had an excellent influence on the management of business units owned so that BUM Desa can contribute more in donations to PADes (Hazzan et al., 2009). With the existence of these facilities, the organization will be able to improve its performance. So the use of information technology strategically has the impact of bringing the organization to increased profitability.

From various things that are theoretical and argumentative, as well as interesting things like the above exposure, strategies are needed to improve the competence of BUM Desa employees and maximize technology as a support for work in organizations, especially BUM Desa which will affect the increasing performance and improve the welfare of BUM Desa employees. The performance of BUM Desa improved due to the management of BUM Desa which has competence and adequate facilities and infrastructure in the management of BUM Desa. From the background of the above problems, the subject matter that will be studied in this paper includes the following: (1) how important is employee competence to the performance of BUM Desa?, and (2) how important is technology to the performance of BUM Desa?.

\section{METHOD}

In this study, the research approach used was a literature review. The aim of the study was to see if competence and technology had an important role in improving bum desa performance. The study's findings are based on a number of theoretical foundations and empirical studies from previous research. 


\section{The Importance of Employee Competence and Technology in Mining Increases The Performance of Village-Owned Enterprises (Bum Desa)}

\section{RESULT AND DISCUSSION}

\section{A. The Importance of Employee Competence Towards Village BUM Performance}

One form of problem in the management of BUM Desa is the competence of human resources (employees) in running BUM Desa is still lacking. Some experts define the term competence" as follows: (1) Competence encompasses an individual's technical and interpersonal knowledge and skills (Robbins, 2013, p. 357). Competence is the knowledge and skills of individuals technically and interpersonally. (2) A competency is an underlying characteristics on individual that is causally related to criterion referenced effective and / or superior performance in a job or situation(Lyle M. Spencer Jr., 2003, p. 21). Competence is related to the basic characteristics of individuals associated with effective and or superior performance standards (3). The IRS Handbook on Competencies: Law and Practise (Nootjarat et al., 2012; Rankin, n.d.), divides competence into two, namely: technical competencies, often referred to as hard competencies or job related competencies, and skills, often referred to as skills). Self concept, attitudes, value traits, and motivation behavioral competencies, often called "soft competencies," are competencies determined by behavior or mental attitude.

Partly from that perspective, the author can conclude that competence is ability, and character influences execution. One model of ability that is widely recognized by academics and professionals is the model of ability put forward by Lyle M. Spencer Jr., (2003). The model is found in Figure 1 below.

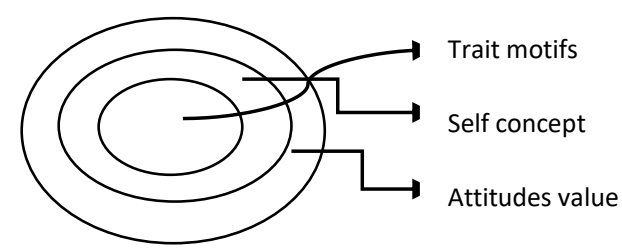

Figure 1.

Source: Competency Model: Lyle M. Spencer Jr., (2003)

That there are 5 characteristics of competence: (1) motive (motive)., consistently is what encourages (motivates individuals to do something) (2) innate traits, physical characteristics, and reactions that are social to what happens in the environment; (3) self-concept, self-value, the way individuals perceive themselves as (4) knowledge (knowledge), information that a person has about something, (5) skills (skills), ability to perform physical and mental tasks (Lyle M. Spencer Jr., 2003). Information and capabilities will be more frequently visible and fairly easy to create through a preparation program. Innate intentions and characteristics that are in a circle in the middle mask factors that are very challenging to evaluate and create. The latter is selfidea, being in the middle circle, implying that mentality, values, and self-esteem can be changed through preparation and psychotherapy or meeting positive progress, despite the fact that it takes up most of the day.

\section{B. The Importance of Competence to The Performance of BUM Desa}

Department of Organizational Behavior at Case Western Reserve University. Before getting into each of the articles, let us examine what competencies are. What is a competency? A competency is defined as a capability or ability. It is a set of related but different sets of behavior organized around an underlying construct, which we call the "intent". The behaviors are alternate manifestations of the intent, as appropriate in various situations or times. For example, listening to someone and asking him or her questions are several behaviors. A person can demonstrate these behaviors for multiple reasons or to various intended ends (Boyatzis, 2008, p. 6).

According to Michael Armstrong (1994) in Sudarmanto, (2015) competence is something that individuals bring into a task in various kinds and levels of behavior.

Meanwhile, according to Ardiansyah \& Sulistiyowati (2018) "competence" is the knowledge, skills, and attitudes of someone who directly affects employee performance. Based on this understanding, competence is information, capacity, and ability that is driven by an individual and applied in performing tasks and work in the work environment. Competence refers to the underlying attributes of behavior that describe the intentions, qualities of individuals, self-ideas, qualities, information, or abilities carried by a person who dominates in the work environment. Every association anticipates achievement. To make this progress requires qualified workers.

Employees who have high competence, such as information, abilities, capacity, and mentality in accordance with the job assigned are always directed to work more productively (Rande, 2016). Michael Zwell in Wibowo 2015, 283-286 states that there are several factors that affect a person's competence, namely, (1) beliefs and values, this is related to trust or confidence 


\section{The Importance of Employee Competence and Technology in Mining Increases The Performance of Village-Owned Enterprises (Bum Desa)}

in himself and others; (2) skills, specifically skills related to performance; the more skilled the employee, the better the performance produced; (3) experience, usually useful for communication in front of a group, making decisions and resolving problems; (4) the characteristics of personality, is an attitude or attitude that is attached to the individual; (5) Motivation, the spirit of work that is always undergoing change, for that it needs to be given appreciation, support, guidance and direction from leaders and colleagues; (6) Emotional issues, emotions tend to be obstacles to improving competence, such as, not being confident, fearing being wrong, or feeling disliked by other members; (7) intellectual ability, which is related to cognitive thinking skills, concept formation, and analytical thinking; (8) organizational culture, influencing employee competence as in the reward, training, and development system.

The importance of competence in running BUM Desa business towards improving the performance of BUM Desa To qualify for BUM Desa's efforts to be ideal, we further develop skills and knowledge, especially for BUM Desa administrators that have an impact on the performance of BUM Desa for the better. Judging from previous research, there are several factors that can affect the performance of BUM Desa. Gede et al. (2013), stated that competence has a significant effect on the performance of BUM Desa, meaning that with good competence owned by employees, it will provide improved performance.

Training and competence had a significant effect on the performance of BUM Desa (Yuli Fitriyani, Radna Nurmalina, Rina Febrianan, 2018). While the results of different studies were found in the research of Fredy (2015), Suwandi (2016) stated that training and competence had no effect on the performance of BUM Desa. In Putra and Hendriani 2020 related to competencies that affect performance with organizational commitment as an intervening factor, where from the results of his research, it is known that competence affects the performance of BUM Desa through organizational commitment. Sisiawan (2013) proves the positive influence of competence on performance. A different study was found in Renah research (2014), which showed no influence between competencies on employee performance. Several studies that have been conducted show that competence has a very important role in the development of BUM Desa performance.

According to Gordon (1998) in Sutrisno (2010), there are several aspects contained in competence, namely knowledge, understanding, ability, values, attitudes, and interests. Competency-based HR can expand boundaries and build companies because, in this case, when individuals working in the organization have the right abilities according to their work, they will really want to be good as long as the ability possessed is useful in increasing production.

The adequacy of implementation is indicated by the degree of achievement in achieving the goal. The success rate includes the quantity of work, good quality of work, and timeliness in completing employment. Employee competence also needs to be evaluated. The function of this evaluation is to be able to see and predict the results of employee performance. Competence can be used as a criterion in determining the results of employee performance. Referring to the results of research conducted by Makawi, Normajatun, and Haliq (2015), it shows the influence of employee competence on performance. Similar research results were published by Pattiasina (2018), Falilah \& Wahyono (2019), Nurjaya et al., (2021), Rijal \& Frianto (2020), Sutedjo and Mangkunegara (2018), Steward V. Hoke, (2018), Efendi \& Yusuf (2021), Azizu, and Sari (2020), Ahyar Rasyid (2018), Dhermawan et al., (2012), and Mizanul I'tidal (2016) stated that competent human resources have a strong impact and influence on performance.

As stated by Spencer in Moeheriono (2009), the relationship between competence and performance is very close and vital, meaning that to further develop its presentation, you must have the ability that is in accordance with the obligations of your work (the right man on the right job). With a focus on the competency approach, it will have an impact on employee performance individually and also relate to the business strategy of a company (Yuvaraj, 2011)

Davis in Mangkunegara (2009) formulated that: 1). Human Performance = Ability + Motivation, performance is the result of competence and motivation, 2). Ability (competence) $=$ Knowledge + Skill, Competence is the result of a combination of knowledge of tasks and responsibilities and work skills owned by employees. 3). Motivation = Attitude + Situation and motivation in the form of the attitude (attitude) of employees in dealing with work situations in the company (situation).

The results of the above exposure can be concluded in real terms that competence can affect the improvement of bum desa performance. In the management of BUM Desa employees who have knowledge, job skills, high responsibility for a job, and good motivation can be found. If this can be applied, it is believed that BUM Desa can develop well as well.

\section{The Importance of Technology to The Performance of BUM Desa}

\section{Information and communication technology}

The word technology, in its true sense, comes from the Latin texere, which means composing, building, making, or composing, so the term technology should not be limited to the utilization of machines, although in terms of thinness, it is not expected to be used in everyday life (Yusuf, 2010). From a broader perspective, technology can include: obtaining frameworks, associations, 


\section{The Importance of Employee Competence and Technology in Mining Increases The Performance of Village-Owned Enterprises (Bum Desa)}

as well as methods. After all, as events turn and times advance, technology is becoming increasingly limitless, so nowadays, technology is an idea related to the types of use and information on devices and capabilities, and what can be done. So technology is a kind of augmentation of the human hand to have the option to exploit nature and the things around it. Therefore, technology basically means working for the satisfaction of human needs. Technology (science and technology) as a whole is all forms of technology related to recovery, sorting (securing), handling, hoarding, dissemination, collection, processing, and presentation of data (Sutrisno, 2010).

In the context of Indonesian culture, information and communication technology (ICT) in a very short time has become a significant structural material in the improvement of today's culture. In many countries, it is considered that understanding ICT, mastering the basic skills of ICT and having ICT ideas are essential for teaching centers, such as reading, writing and numeracy.

UNESCO states that all developing and non-industrial countries need to approach ICT and provide the best instructive offices so that children are ready to take full part in today's culture and can take part in information countries. Because of the rapid progress of ICT, consistent changes are quite difficult for parties, ranging from teaching services, teachers, and distributors. Restricted assets require a school framework. After all, ICT is critical to the future well-being of industry and business, so an interest in hardware, instructor training, and support administration for ICT-based education programs should be an administrative necessity (Rusman, 2011).

In general, technology is all involved in the retrieval, collection, processing, storage, dissemination, and presentation of information. According to Puskur Kemendiknas, the scope of information and communication technology (ICT) covers two aspects, namely:

a) Information Technology encompasses all processes, aids, manipulation, and management of information.

b) Communication technology encompasses all aspects of using aids to process and transfer data from one device to another.

As shown by the Oxford English Word reference in Aji Supriyanto, information systems are equipment and programming, and can combine organization and media communication that are mostly in a business environment. Often, information systems are essential for business practices that use PC electronic devices. So basically, the term "information system" is an innovation that involves the PC as the main gadget to process information into useful data (Aji Supriyanto, 2015).

\section{The Importance of Technology in the Performance of BUM Desa}

The organization's need for information increases in line with the development of the organization, especially the new BUM Desa organization developing in the current era. Making decisions, planning, organizing, directing, and controlling organizational activities in a BUM Desa organization requires fast and accurate information. The importance of fast and accurate information in BUM Desa organizations requires an information system that is responsive to the needs of the organization. Seeing that many BUM Desa organizations are now changing their information systems that, in the past, used manual systems into systems based on information technology.

In the current era of globalization, the development of information technology (IT) is growing rapidly. Information technology is a device used for reasons related to handling information, including handling, obtaining, assembling, storing, and controlling information in various ways to convey quality data and make important, precise, and ideal specific data. It can also be used for individual, business, and governmental purposes, which is vital data for direction. Muzakki et al., (2016) uses information technology to handle information, organizational frameworks to connect one PC to another on a case-by-case basis, and communication media innovations are used so that information can be spread and spread throughout the world.

A 2000 study by DEW (Zentrum für Europäische Wirtschaftsforschung) in 2000, cited in Falk (2001), found that more than 54\% of 4149 associations in Germany changed their data frameworks from manual frameworks to frameworks dependent on information technology. It is largely considered that technology has a very strong impact in helping associations with the implementation of further development and, in this way, achieve excellence.

Several other studies that have been conducted before, such as research conducted by Ardiany (2018), Djatikusumo (2016), Widagdo, Pamilih, Putut, Susanto (2015), and Ellitan (2003), found similar things that state that technology and its development have a strong influence on the performance of an organization.

According to Kadir \& Triwahyuni (2003)"Information technology is a group of instruments that help work with data and make efforts related to data handling." It is explained that information technology is a combination of PC innovation and correspondence innovation. A PC innovation is a set of tools used to convert information into data that can be used as directional material. Meanwhile, the fundamental use of information technology universally is to help address problems with high innovation and make individuals more active in using it. The use of information technology (IT) to help various needs and 


\section{The Importance of Employee Competence and Technology in Mining Increases The Performance of Village-Owned Enterprises (Bum Desa)}

improve associations, people, and organizations will definitely bring something positive. However, remember that IT can make us more meaningful individuals by engaging us in positive things. The benefits of information technology (IT) for positive things will certainly get a lot of help from various (Muzakki, 2016).

The various information systems literature is full of modeling of factors associated with the use or acceptance of IT by workers, decision-makers, and managers. Experts also found behavioral management information systems (SIM) approaches in psychology approaches, namely Theory Reassoned Action (TRA) and Technology Acceptance Model (TAM). The Theory of Reasoned Action (TRA) is a theory of reasoned action with the premise that a person's reactions and perceptions of something will determine the person's attitude and behavior. According to the theory of uses and gratifications, currently the media environment is changing rapidly due to the influence of information technology. In the form of changes that occur in the media environment, there are terms like "multimedia" or "internet" with features like email, newsgroups, and mailing lists, and the World Wide Web, so that communication is more widely scoped and diverse. Although the results vary, the theory of uses and gratifications can make an important contribution to understanding as the digital age shifts further and media users are faced with more choices (Severin, Werner J., Tankard (2014). The assumptions underlying the theory of benefits and gratification are: 1). To achieve the goal directed at using mass media, 2). The types of media and media content to be interpreted are chosen by the institution. 3) In addition to the media, there is also a source of need, and the mass media must compete with it. The sources are, for example, family, friends, interpersonal communication, leisure activities, sleep, and watching. 4). the audience is aware of its own needs and is able to express them when asked. They are also aware of the purpose of the media's use.

The reaction and perception of information technology (IT) users will affect their attitude towards acceptance of the technology. One of the factors that can affect it is the user's perception of the usefulness and ease of use of IT as a reasonable action in the context of technology users. One of the factors that can affect it is the user's perception of the usefulness and ease of use of IT as a reasonable action in the context of technology users. The Technology Acceptance Model (TAM) is one of the models built to analyze and understand the factors that influence the acceptance of the use of computer technology, first introduced by Fred Davis in 1986. TAM is the result of the Theory of Reasoned Action (TRA), which was first developed by Fishbein and Ajzen in 1980. Performance comes from the word "job performance" or "actual performance," which means work performance or actual achievement achieved by someone. Performance is the result of the quality and quantity of work carried out by an employee or organization in carrying out its functions in accordance with the responsibilities given to him. Performance is an achievement achieved by employees or organizations in carrying out their work in accordance with the standards given by (Muzakki, 2016;171). It can be concluded that technology has a strong influence on the performance of organizations, especially BUM Desa. Without technology in the BUM Desa organization, all organizational activities in the form of information, marketing, and planning will be slow, which has an impact on the slowing performance of BUM Desa.

\section{Use of Information Technology at BUM Desa}

Information technology plays a very important role, especially in the business world, especially in working on bum desa presentation. Organizations without using IT will often be sagging and undermined by liquidation. Many business competitors have started to use technology to help with their maintenance and increase their profits. As Mardhani Riasetiawan (2005) points out, technology fills several roles, specifically collecting information, handling information, overseeing information, controlling information, and creating information.

Some of the capabilities that involve a data framework in a business process consist of handling exchanges, checking for updates, and deleting data. The presence of technology-based information systems alludes to the reasons for the information system itself. For a while, as Wilkinson, Cerullo, Raval (2000) points out, information systems support the capacity to provide data to administration only as an aid method for an organization's daily functional exercises. The main benefit of technologybased information systems is that they are on the web and are constant. Reports can be created directly from information exchanges so as to reflect the current status of business tasks. All recorded exchanges can be either softcopy or printed versions, with the aim of being followed without any problems.

Currently, the utilization of technology among existing BUM Desa is still not boosted. The agreement is still made physically by listening to the talk of others, so that the advertising of goods is currently at the level of the nearest occupant as is. The use of IT, particularly by internet businesses in expanding a piece of the pie, is not ideally finished where these are opportunities and opportunities that should be solved by an increasingly innovative turn of events. The utilization of technology not only aims at the things to be promoted but also focuses more on further developing human resource capabilities. BUM Desa has so far used information technology (IT) in advertising and online sales, also known as e-commerce. 


\section{The Importance of Employee Competence and Technology in Mining Increases The Performance of Village-Owned Enterprises (Bum Desa)}

Judging from the business settings, the advancement of ICT as a web has provided a breakthrough effect that has created another worldview in the business world as computerized advertising, which began in the mid-1970s with developments such as exchanges and electronic asset moves (Abdurrahim, 2011). One of the reasons for the rapid advancement of online business is the increase in organizational conventions and programs, and, of course, the most central reason is the growing competition and different business pressures. Furthermore, electronic businesses combine all the things that must be completed using communication and data technology (ICT) to lead business exercises between associations and from associations to buyers (Spat et al., 2000). In leading a business electronically, the ICT framework is used to connect with buyers, colleagues, and providers.

The utilization of the web causes the business cycle to get better. With the utilization of e-business, organizations need to make information available on their data framework so that organizations can provide data to buyers, colleagues, and providers and run electronically with them using the web. Clients' global data transfer capacity continues to grow. Most recently, the absolute transmission capacity of organization administrators around the world reaches 1 terabyte per second. The principal improvement is the presence of real-time features through the web to the home organization or FTH (Fiber To The Home). Thus, the worldwide shortage of transfer speeds is getting bigger. What's more, the use of public advanced publications for worldwide apps (e.g., Google and Facebook) reached USD 800 million in 2015, while computerized marketing was not taxing.

Using promotions with e-business or e-commerce and bum desa goods offerings in particular, can be done throughout the region without time restrictions and at a very minimal price from regular promotions so that donations of goods or administration can be done anytime and anywhere. As demonstrated by research directed by Mahmudi \& Damayanti (2020), Dwi Pristiani (2018), Hastriyandi \& Munandar (2018), Nootjarat et al., (2012), Rosmadi (2021), and Rika Fatimah (2019), technology has a tremendously solid impact on improving bum desa performance. The maximum use of technology makes it easier for village managers to work either in advancing or promoting an item, looking for data or information, or arriving at the progress of BUM Desa.

\section{CONCLUSIONS}

See some of the forms of discussion above as to the conclusions that can be made:

a) Competency factors play a significant role in improving bum desa performance.In order for the management of BUM Desa to be better, employees must have knowledge, job skills, high responsibility for a job, and good motivation. If this can be applied, it is believed that the existing village bum can develop well as well.

b) Technology has an important role and has a strong impact on the performance of organizations, especially BUM Desa. Without technology in the BUM Desa organization, all organizational activities in the form of information, marketing, and planning will be slow, which has an impact on BUM Desa performance slowing down. The maximum utilization of technology makes it easier for BUM Desa managers to work well in promoting a product, finding information, and accessing the development of BUM Desa.All paragraphs must be indented. All paragraphs must be justified, i.e. both left-justified and right-justified.

Suggestions that can be made include:

a) For bum desa managers, in improving the performance of bum villages, it is needed to improve the competence of existing employees by providing training on the management of BUM Desa to become more professional in their fields.

b) So important is the role of technology in increasing the performance of BUM Desa, advice is given to BUM Desa management to prioritize technology utilization training in the form of applications for employees to support BUM Desa activities such as ecomercial, where this application helps BUM Desa in marketing products through online media.

\section{REFERENCES}

1) A.O'Brien, james. (2008). Introduction to Information Systems. Jakarta: Salemba Empat.

2) Abdul Maulana, U. N. S. (2016). Nawacita Concept in National Development.

3) Abdurrahim, M. F. H. (2011). Implementation of eBusiness in Indonesia. Master in Agribusiness Management Bogor Agricultural University.

4) Adisasmita, H. R. (2013). Rural Development (p. 13). Graha IImu.

5) AHYAR RASYID. (2018). The existence of village-owned enterprises (bumdes) in the implementation of village-scale local authority in the Gangga sub-district, North Lombok regency. Advanced Optical Materials, 10(1), 1-9. https://doi.org/10.1016/PhysRevB.101.089902\%0Ahttp://dx.doi.org/10.1016/j.nantod.2015.04.009\%0Ahttp://dx.doi.or g/10.1038/s41467-018-05514-9\%0Ahttp://dx.doi.org/10.1038/s41467-019-13856-1\%0Ahttp://dx.doi.org/10.1038/s 41467-020-14365-2\%0Ahttp://dx. doi.org/1 

Enterprises (Bum Desa)

6) Aji Supriyanto. (2015). Introduction to information technology. Salemba Infotek.

7) Alfirdausi, A. A., \& Riyanto, G. (2020). The Role of Village Owned Enterprises (BUMDes) on Efforts to Increase Original Village Income (PADes) and Village Community Welfare (Case Study On Tirta Mandiri Bumdes in Ponggok Village, Polanharjo District, Klaten Regency). Journal of Applied Economics in Developing Countries, 4(2), 64-71. https://jurnal.uns.ac.id/jaedc/article/view/44402

8) Ardiansyah, Y., \& Sulistiyowati, L. H. (2018). The Influence of Competence and Emotional Intelligence on Employee Performance. Inspirational Journal of Business and Management, 2(1), 91-100.

https://doi.org/10.33603/JIBM.V2I1.1064

9) Ardiany, Y. (2018). The Effect of Information Technology Governance Mechanism on Organizational Performance with Strategic Alignment as an Intervening Variable. Journal of Profiet, 2(46), 141-147.

10) Boyatzis, R. E. (2008). Competencies in the 21st century. Journal of Management Development, 27(1), 5-12. https://doi.org/10.1108/02621710810810840730

11) Dhermawan, A. A. N. B., Sudibya, I. G. A., \& Utama, I. W. M. (2012). The Influence of Motivation, Work Environment, Competence, and Compensation on Job Satisfaction and Employee Performance in the Bali Provincial Public Works Office. Matrix: Journal of Management, Business Strategy and Entrepreneurship.

a. https://ojs.unud.ac.id/index.php/jmbk/article/view/2203

12) Djatikusumo, K. N. (2016). The Influence of the Use of Information Technology and Computers on Organizational Performance (Case Study in MSMEs in Malang City). Industry Research Workshop and National Seminar: IRONIC, July, 66-71.

13) Dwi Pristiani, Y., \& Pancasila and Citizenship, P. (2018). Sanankulon Village-Owned Enterprises are Administrative and Literate to Grow and Develop the Creative Economy of the Sanankulon Village Community, Sanankulon District, Blitar Regency: ABDINUS Journal: Jurnal Pengabdian Nusantara, 1(2), 144-151.

https://doi.org/10.29407/JA.V1/2.11743

14) Dwiyanti, N. K. A., Heryanda, K. K., \& Susila, G. P. A. J. (2020). The Effect of Competence and Work Motivation on Employee Performance at Pd Bpr Bank Buleleng 45. Prospects: Journal of Management and Business, 1(2).

https://doi.org/10.23887/pjmb.v1i2.23154

15) Efendi, S., \& Yusuf, A. (2021). Influence Of Competence, Compensation And Motivation On Employee Performance With Job Satisfaction As Intervening Variable In The Environment Of Indonesian Professional Certification Authority. International Journal of Economics, Business and Accounting Research (IJEBAR), 5(3).

https://doi.org/10.29040/IJEBAR.V5I3.3377

16) Economics, J., Bisnis, D., Kartika, L. N., Bisnis, F., Kristen, U., Wacana, D., \& Sugiarto, A. (2014). The Influence of Competency Levels on the Performance of Office Administration Employees. Journal of Economics and Business, 17(1), 73-90. https://doi.org/10.24914/JEB.V17I1.240

17) Ellitan, L. (2003). The Role of Resources in Increasing the Effect of Technology on Productivity. Journal of Management and Entrepreneurship, 5(2), 156-170-170. https://doi.org/10.9744/jmk.5.2.pp.156-170

18) Falilah, \& Wahyono. (2019). The Influence of Organizational Culture, Motivation, and Competence on the Performance of Transportation Service Employees in Batang Regency. Journal.Unnes.Ac.Id, 8(3), 889-910.

https://doi.org/10.15294/eeaj.v8i3.35006

19) Gede, A. A., Pramana, K., \& Sudharma, N. (2013). Effect of Compensation, Physical Work Environment and Work Discipline on Employee Performance. E-Journal of Management, 2(9).

https://ojs.unud.ac.id/index.php/Management/article/view/5723

20) H, hardin, Azizu, A. M., \& Sari, W. O. D. P. (2020). The Influence of Competence, Organizational Culture, Spiritual Leadership on Organizational Behavior and Its Impact on Lecturer Performance at Higher Education in Baubau City. International Journal of Management Progress, 1(2), 50-72. https://doi.org/10.35326/IJMP.V1/2.784

21) Hastriyandi, H., \& Munandar, M. (2018). Application of an Online-Based Marketing System on Products of Village Owned Enterprises (Bumdes) "Joint Business" in Sebayan Village, Sambas Regency. Amaliah: Journal of Community Service, 2(2), 189-195. https://doi.org/10.32696/ajpkm.v2i2.201

22) Hazzan, O., Leron, U., Hansson, C., Dittrich, Y., Gustafsson, B., Zarnak, S., Chow, T., Cao, D.-B., Burgess, T., Hwarng, B., Shaw, N., De Mattos, C., Kettunen, P., Pesonen, LTT, Salminen, SJ, Ylén, J.-P., Riihimäki, P., Berger, H., Layman, L ., ... Stein, B. (2009). Preface. Journal of Systems and Software, 52(2). 
23) Kadir, A., \& Triwahyuni, T. C. (2003). Introduction to Information Technology. Andi Yogyakarta. 1. COMPUTER, SCIENCE 2. INFORMATION TECHNOLOGY, Introduction to Information Technology / By Abdul Kadir and Terra Ch Triwahyuni, 2003(2003).

24) Kenneth C Laudon - Jane P Laudon -. (2004). Management information systems. Prentice Hall.

25) Kurniawan, M. (2013). The Influence of Organizational Commitment, Organizational Culture, and Job Satisfaction on the Performance of Public Organizations (Empirical Study on SKPD of the Kerinci Regency Government). Journal of Accounting, 1(3). http://ejournal.unp.ac.id/students/index.php/akt/article/view/672

26) Lyle M. Spencer Jr., S. M. S. (2003). Competence at Work: Models for Superior Performance.

27) Mahmudi, A. A., \& Damayanti. (2020). Application of Information Technology and Management Development of BUMDES “Bangun Yuwana” Sumberjo Village, Rembang District, Rembang Regency. Journal of Vocational Service, 01(03), 164-167.

28) Makawi, U., Normajatun, N., \& Haliq, A. (2015). Analysis of the Influence of Competence on the Performance of Employees of the Banjarmasin City Industry and Trade Office. AL-ULUM: Journal of Social Sciences and Humanities, 1(1). https://doi.org/10.31602/ALSH.V1I1.307

29) Mangkunegara, A. A. A. P. (2009). Company Human Resources Management. PT REMAJA ROSDAKARYA.

30) Mardhani Riasetiawan. (2005). Theoretical Review of Accounting Information Systems.

31) Lucky Nara Rosmadi's Mascarto. (2021). Implementation of Business Strategy during the Covid-19 Pandemic. Journal of IKRA-ITH Economics, 4(1).

32) Mizanul I'tidal, A. J. (2016). The influence of competence, compensation, work motivation, and education on the performance of lecturers at STIMIK AKBA Makassar. Competitiveness: Journal of Management and Business, 2.

33) Moeheriono. (2009). Competency-Based Performance Measurement. Indonesian Ghalia.

34) Muzakki, M. H., Susilo, H., \& Yuniarto, S. R. (2016). The Effect of Information Technology Use on Employee Performance (Study on Employees of PT. TELKOM Central Division Regional V Surabaya). Journal of Business Administration (JAB), 39(2), 169-175.

35) Nootjarat, R., Chantatub, W., \& Chongstitvatana, P. (2012). Towards an Understanding of how Information Technology Enables Innovation-the Innovators' Perceptions. Distances, 6(12).

36) Nurjaya, N., Affandi, A., Ilham, D., Jasmani, J., \& Sunarsi, D. (2021). The Influence of Human Resource Competence and Ability to Utilize Technology on Village Apparatus Performance at the Village Head's Office in Gunungkidul Regency, Yogyakarta. JENIUS (Scientific Journal of Human Resource Management), 4(3), 332. https://doi.org/10.32493/jjsdm.v4i3.10460

37) Pattiasina, M. (2018). The Influence of Human Resource Competence on Employee Performance at PT. Bank Tabungan Negara, Tbk. Manado Branch Office. 1-6.

38) Putra, A. S., \& Hendriani, S. (2020). The Effect of Training and Competence on Employee Performance Mediated by Commitment to Bumdes Managers in Kuansing Regency. KIAT Journal of Economics, 31(2), 91-99. https://journal.uir.ac.id/index.php/kiat/article/view/2886

39) Rande, D. (2016). The Influence of Competence on Employee Performance at the Department of Transportation, Communication and Information, North Mamuju Regency. Catalog, 4(2). http://jurnal.untad.ac.id/jurnal/index.php/Katalogis/article/view/6537

40) Rankin, N. (n.d.). The IRS Handbook On Competencies: Law \& Practice. Lexis Nexis U.K.

41) Rijal, A. F. N., \& Frianto, A. (2020). The Effect of Competence on Employee Performance through Job Satisfaction: Literature Study. BIMA: Journal of Business and Innovation Management, 3, 49-58.

42) Rika Fatimah, P. (2019). Developing the Quality of Village Owned Enterprises (Q-BUMDes) to Preserve Community Economic Resilience and Adaptive Welfare: Designing a Village Entrepreneurship System Using the Tetrapreneur Model. Journal of Youth Studies, 7(2), 122. https://doi.org/10.22146/studipemudaugm.39551

43) Robbins, S. . (2013). Organizational Behavior Global Edition (15th ed.). Pearson Education Limited.

44) Rosmadi, M. L. N. (2021). Implementation of Business Strategy during the Covid-19 Pandemic. Journal of IKRA-ITH Economics Vol 4 No. 1 March 2021, 4(1).

45) Rusman. (2011). Information and Communication Technology Based Learning. PT. King Grafindo Persada.

46) Sedarmayanti. (2017). Increased Productivity at PT. X. Journal of Chemical Information and Modeling, 53(9), 16891699. file:///C:/Users/User/Downloads/fvm939e.pdf 


\section{Enterprises (Bum Desa)}

47) SEVERIN, Werner J., TANKARD, J. W. (2014). Communication Theory: History, Methods, and Applications in Mass Media Edition 5. Kencana Prenada Media Group.

48) Soetrisno, A. P., \& Gilang, A. (2018). The Effect of Competence on Employee Performance (Study at PT. Telekomunikasi Indonesia Tbk Witel Bandung). JURISMA: Journal of Business \& Management Research, 8(1). https://doi.org/10.34010/jurisma.v8i1.998

49) Steward V. Hoke. (2018). The Effect of Competence, Organizational Commitment and Compensation on Employee Performance at Pt.Marga Dwitaguna Manado, North Sulawesi. EMBA Journal: Journal of Economic Research, Management, Business And Accounting, 6(1), 1-11. https://doi.org/10.35794/emba.v6i1.18697

50) Sudarmanto. (2015). HR Performance and Competency Development: Theory, Dimensions of Measurement, and Implementation in Organizations. Student Library.

51) Sudibia, I. K. (n.d.). ISSN 2303-017 Effect of Capital, Length of Business, Technology on Labor Productivity and Income of MSMEs in North Denpasar Faculty of Economics and Business, Udayana University (Unud), Bali, Indonesia ABSTRACT INTRODUCTION According to Sirojuzilam (2008: 16. 2209-2238.

52) Suparmoko and Irawan. (2010). economic development. BPFE, UGM.

53) Suriadi, A., \& Thamrin, H. (2019). Institutional Management Model of Joint Village-Owned Enterprises (BUMDes) in North Sumatra. Budapest International Research and Critics Institute (BIRCI-Journal): Humanities and Social Sciences, 2(3), 458-469. http://bircu-journal.com/index.php/birci/article/view/451/0

54) Sutedjo, A. S., \& Mangkunegara, A. P. (2018). The Influence of Competence and Work Motivation on Employee Performance at PT. The Core of the Prosperous Gardens. BISMA (Business and Management), 5(2), 120. https://doi.org/10.26740/bisma.v5n2.p120-129

55) Sutrisno. (2010). Innovative Learning Based on Technology and Communication. Echo Persada.

56) Tallon, P. P., \& Pinsonneault, A. (2011). Competing perspectives on the link between strategic information technology alignment and organizational agility: Insights from a mediation model. MIS Quarterly: Management Information Systems, 35(2). https://doi.org/10.2307/23044052

57) Wibowo. (2015). Work management. Second Edition. PT. King Grafindo Persada.

58) Widagdo, Paelek, Putut, Susanto, D. T. (2015). The Effect of Technology Suitability on Tasks (Task Technology Fit) on Individual Performance in Using Information Technology (Case Study: Mulawarman University). Proceedings of the XXIII Technology Management National Seminar, August, 1-12.

59) Widjaja. (2014). Village autonomy: is genuine, complete and complete autonomy. In Ed. 1, Cet. 7 (p. 76 ). Jakarta:: Rajawali Press, 2014.

60) Wilkinson, Cerullo, Raval, W. on W. (2000). Accounting Information system essential Concepts and Applications (4th ed). John Willry \& Sons.

61) Yuli Fitriyani, Radna Nurmalina, Rina Febrianan, E. S. (2018). Mobilizing the Village Economy through Village Owned Enterprises (Bumdes). Advanced Optical Materials, 10(1), 1-9.

https://doi.org/10.1016/PhysRevB.101.089902\%0Ahttp://dx.doi.org/10.1016/j.nantod.2015.04.009\%0Ahttp://dx.doi.or g/10.1038/s41467-018-05514-9\%0Ahttp://dx.doi.org/10.1038/s41467-019-13856-1\%0A http://dx.doi.org/10.1038/s41467-020-14365-2\%0Ahttp://dx. doi.org/1

62) Yusuf, P. M. (2010). Instructional Communication Theory and Practice (Ed.1, Cet.). Earth Literature.

63) Yuvaraj, R. (2011). Competency Mapping-A DRIVE FOR INDIAN INDUSTRIES. International Journal of Scientific \& Engineering Research, 2(8). http://www.ijser.org 